\title{
A RENDSZERVÁLTOZÁS UTÁNI VÁROSSÁ AVATÁSOK MAGYARORSZÁGON
}

\author{
(The City-proclamations in Hungary after the System-change)
}

\author{
SZEPESI GÁBOR
}

Kulcsszavak:

városodás és városiasodás a rendszerváltás után a törvényi szabályozás változása területi különbségek népesedési folyamatok az új városokban a szuburbanizáció magyarországi sajátosságai

A rendszerváltás fordulópontnak bizonyult az urbanizáció folyamatában is hazánkban. 1990 után ugyanis ugrásszerüen megnött a városok száma, és ezzel párhuzamosan jelentösen megnött a városi lakosok aránya is. Mindez összefügg a várossá nyilvánitás törvényi kereteinek megváltozásaival is. Az 1999. évi önkormányzati szabályozás objektív és szubjektiv feltételeknek is teret enged a várossá avatásnál. Az új városok területi megoszlása azonban rendkivül egyenlótlen, és tovább növeli a szakadékot a kevésbé városodott és az átlagnál jóval urbanizáltabb megyék között. Különösen jelentôs az ủj városok száma a Budapest környéki agglomerációban; ezek a települések a várossá avatás óta is jelentốsen növelték népességüket, többnyire a föváros rovására. A szuburbanizáció azonban nem feltétlenül nyugat-európai mintára játszódik le Magyarországon.

\section{A várossá avatások mechanizmusa és története a rendszerváltozás után}

A hazai társadalomföldrajz egyik nagy érdeklódést kiváltó témájává vált az 1990 óta bekövetkezett várossá nyilvánítások kérdésköre. Azért is számíthat egyfajta „korszakhatárnak” a rendszerváltás, mivel azóta a városok száma sokkal gyorsabb ütemben nő, mint az azt megelözó évtizedekben.

Mindez természetesen összefügg a várossá nyilvánítás törvényi kereteinek megváltozásával is. 1990 elött a várossá válással kapcsolatosan két fontos szabályozás is született. A 23/1974. ÉVM-MTTH számú közlemény értelmében az Országos Településhálózatfejlesztési Koncepció besorolása alapján középfokú, illetve részleges középfokú központokat javasoltak várossá nyilvánítani, amelyeknek szigorú kritériumoknak kellett megfelelniük. Később a 7010/1983. ÉVM számú irányelve már lazított a nagyközségek várossá válásának feltételein, és az ezzel kapcsolatos szempontokat csupán irányadónak tekintették. Ugyanakkor a várossá válásra vonatkozó kérelemhez csatolni kellett többek között a KSH segítségével összeállított mellékletet is, amely az élet számtalan területére vonatkozó statisztikai adatokról tájékoztatott.

Ilyen előzmények után keruilt sor a rendszerváltást követó elsỏ szabályozásra, az ekkor megalakuló önkormányzatokkal kapcsolatos 1990. évi LXV. törvény meghozatalára, melynek értelmében olyan község (az 1994. évi LXIII. törvény módosítása után nagyközség) lehetett város, amely esetében a város cím használatát a település fejlettsége, 
térségi szerepe indokolja. Mindehhez azonban nem csatoltak semmilyen feltételrendszert, ami túlzott liberalizmushoz vezetett a várossá nyilvánításokkal kapcsolatosan.

Ezek után a várossá nyilvánítás vonatkozásában két „tábor” alakult ki a kilencvenes években. Az egyik csoportosulás (melynek hívei nyilvánvalóan sokallották az új városok számát) szigorúbb szabályozást követelt, a másik fél eközben minden településnek megadta volna a várossá válás lehetôségét. Ugyanakkor sokan a két vélemény között helyezkedtek el, miszerint szükség van meghatározott szempontok figyelembevételére a várossá avatás elött, de az elbírálásnál tekintettel kell lenni az adott telepulés sajátosságaira és adottságaira is. Így az ezen a véleményen lévők egyszerre voltak hívei az objektív és a szubjektív feltételeknek (Kiss 1997.)

Mindezek után került sor a mai napig érvényben lévő 1999. évi, a területszervezési eljárásról szóló XLI. törvény meghozatalára. A törvény számos területi változás (pl. településegyesítés, új község alakítása stb.) mellett meghatározza a várossá nyilvánítás feltételeit. Ebben a törvényben jól tükröződik a szabályozásnak az előző években, évtizedekben történő átalakulása, hiszen részben megtartotta az 1990. évi törvény egyes elemeit, ugyanakkor kiegészítette bizonyos feltételekkel, részben az Alkotmánybíróság nyomására (1. ábra). Megjegyzendó, hogy a 2006-ban megalakult kormányban a belügyminiszteri feladatokat lényegében az önkormányzati és területfejlesztési miniszter tölti be, így az ő javaslatait mérlegeli a köztársasági elnök.

\section{1. ÁBRA}

A várossá válás szabályozásának folyamata

(The Order of the City-proclamations)

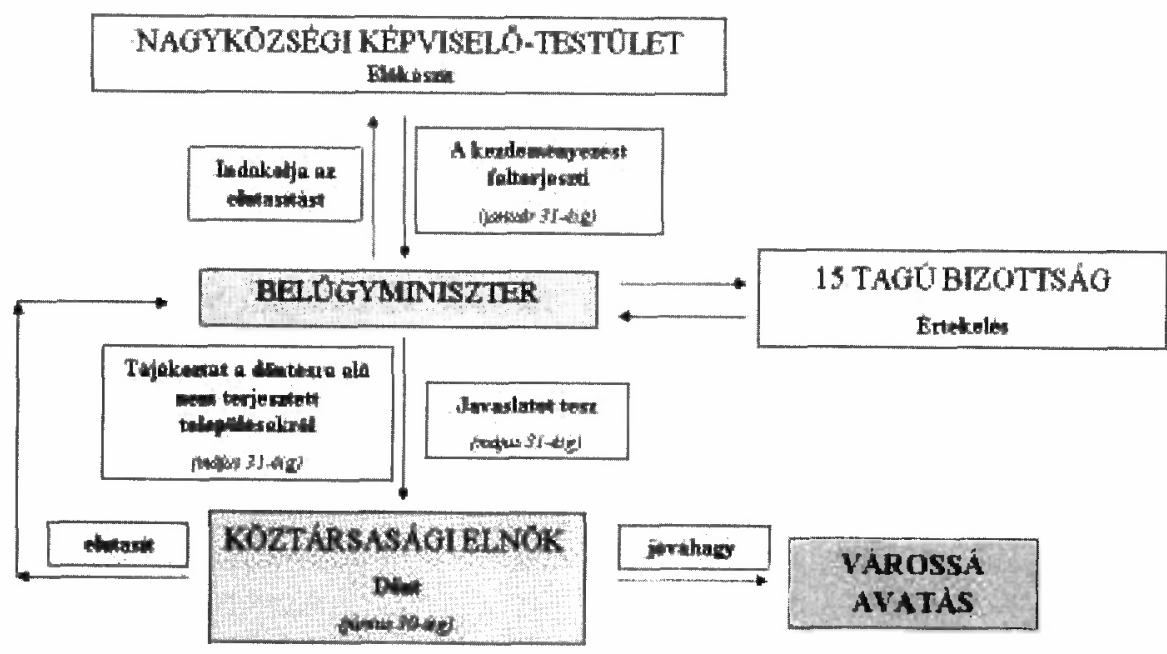

Forrás: CompLex CD Jogtár (2008). 
A törvény értelmében továbbra is a nagyközség fejlettsége, térségi szerepe a meghatározó a várossá válás folyamatában, ugyanakkor a nagyközségi képviselötestületnek részletes értékelésben kell bemutatnia a település fenti szerepét.

A részletes értékelésnek tekintettel kell lennie a település földrajzi fekvésére, a településhálózatban elfoglalt helyére, a népességszám alakulására és összetételére, a gazdasági fejlettségre és szerkezetére, a foglalkoztatottság helyzetére, az infrastrukturális feltételrendszerre, az intézmények szerepére, továbbá a történelmi múltra, a szellemi és kulturális életre, valamint az önkormányzati vagyonra. Amint látható, az itt meghatározott szempontrendszer tartalmaz objektív és szubjektív, nehezen számszerüsíthető elemeket is, így bizonyos tekintetben a fenti, „köztes” véleményen lévők akarata is megjelenik a törvényben.

A városok gombamód történó szaporodása felveti azt a kérdést is, hogy mi motiválja az egyes települések várossá válását. A közvélemény általában anyagi okokkal magyarázza a várossá fejlődés előnyeit, mondván, hogy a városok nagyobb pénzügyi támogatásban részesülnek a központi költségvetés vagy az önkormányzatok jóvoltából. Amennyire igaz volt ez a rendszerváltás elött (bár, akkor is csak bizonyos, a megyei tanácsok által preferált települések esetében), annyira nem helytálló 1990 után. Leszámítva azt, hogy a személyi jövedelemadóból eredő bevételt kedvezőbben juttatják a városok számára, azok közvetlen anyagi hasznot nem húznak új rangjukból. Más kérdés, hogy közvetetten már lehetnek anyagi előnyei a várossá válásnak, hiszen az önkormányzatok normatív központi ellátásban részesülnek az egy före jutó fejkvóták és a részben meghatározott feladatok kvótái (pl. óvodai férőhelyek, iskolai tanulók száma, szociális ellátásban részesülők száma stb.) alapján (Beluszky-Gyốri 1999). Jóllehet e támogatás független a települések jogállásától, a városok nagyobb népességszámuk és fejlettebb infrastruktúrájuk alapján jobban részesülhetnek a központi költségvetésből. ${ }^{1}$ Mindezek figyelembevételével más motivációs tényezöket kell keresnünk a várossá válással kapcsolatban. A városi rang megszerzése ma is presztízskérdésnek számít. Például sok, egykor különféle rangokkal (pl. mezóvárosi, illetve járási székhely) rendelkező település azért jelölte meg célként a városi cím visszaszerzését, hogy ezáltal sérelmeik orvoslását elérjék. Tehát ebben az esetben a történelmi múlt, a hagyományok jelentenek motivációs elemet. Ösztönözheti a várossá válást más települések várossá nyilvánítása, a köztük fennálló verseny (különösen egyazon megyében lévő települések esetében.). Arra is van példa, hogy egy település azért célozza meg a városi rangot, mert így az ott élő emberekben plusz energiákat szabadít fel (Kiss 1997), és így képesek többet áldozni a reménybeli városi településért, mint a faluért. Ugyanakkor sok esetben a városi cím odaítélése nyomán növekszik meg a településen élök aktivitása, hiszen ekkor a lakosság azt igyekszik bizonyítani, hogy a település valóban megérdemelte a városi rangot (Szigeti 1997).

Ami a városok számának alakulását illeti, csaknem ugyanannyi város jött létre 1945 és 1990 között, mint az azt követö 17 évben (2. ábra). Ha mindennek egy évre levetített mértékét nézzuik, még szembetűnőbb a különbség: a rendszerváltás elötti évtizedekben évente $2-3$, azt követően pedig 7-8 új város avatására került sor (3. ábra). ${ }^{2}$ 
Szepesi Gábor : A rendszerváltozás utáni várossá avatások Magyarországon.

Tér és Társadalom 22. évf. 2008/2. 53-70. p.

\section{2. ÁBRA}

$A$ városok száma a rendszerváltás elött és után (The Number of Cities before and after the System-change)

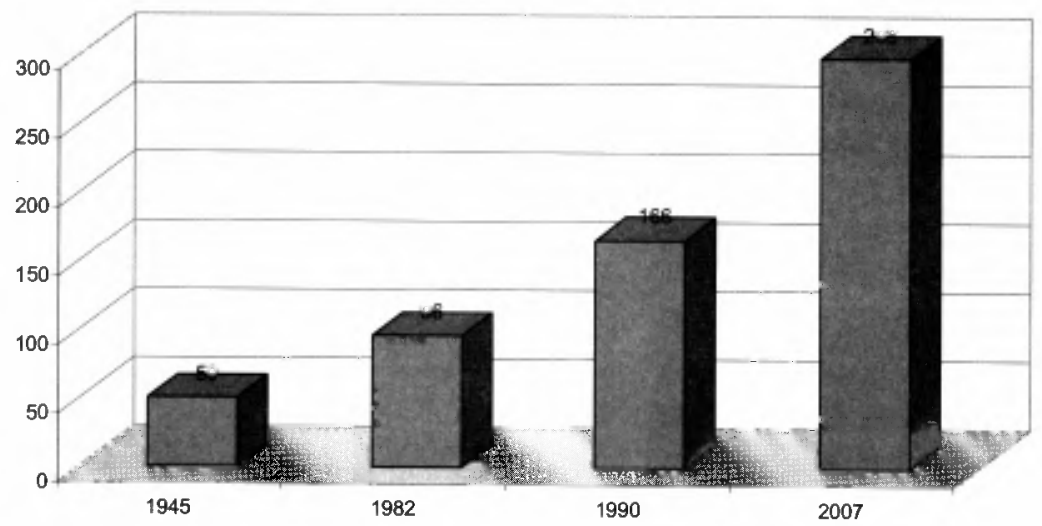

Forrás: Magyar Statisztikai Évkönyv (2006).

\section{3. ÁBRA}

A városok számának évenkénti változása 1990 után

(The Year by Year Change of the Number of Cities after 1990)

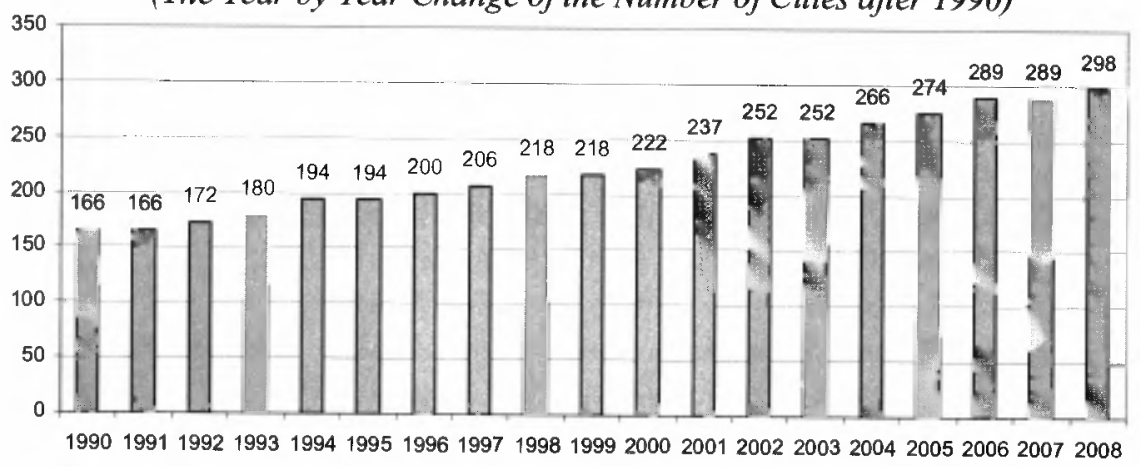

Forrás: Magyar Statisztikai Évkönyv (2006).

A 3. ábrán jól látszik, hogyan gyorsult fel a városodás üteme Magyarországon a rendszerváltás után. Kiemelkedik mindenekelött a 2004-es év, amikor az új városok száma elérte a 18-at. Egyaránt 15 városavatásra került sor 2000-ben, 2001-ben és 2005-ben is. Minden negyedik év mentes a várossá avatásoktól, hiszen a törvény nem engedélyezi ezt az önkormányzati általános választás évében. Ugyanakkor az utóbbi években az is megfigyelhető, hogy minden negyedik év különösen nagy számú várossá nyilvánítást hoz. Ezek az évek egybeesnek a választások előtti utolsó évekkel, ami kiemeli a már fentebb is említett politikai tényező szerepét a várossá avatásokban. 


\section{4. ÁBRA}

$A z$ új városok megoszlása megyénként

(The Regional Distribution of the Cities by Counties)

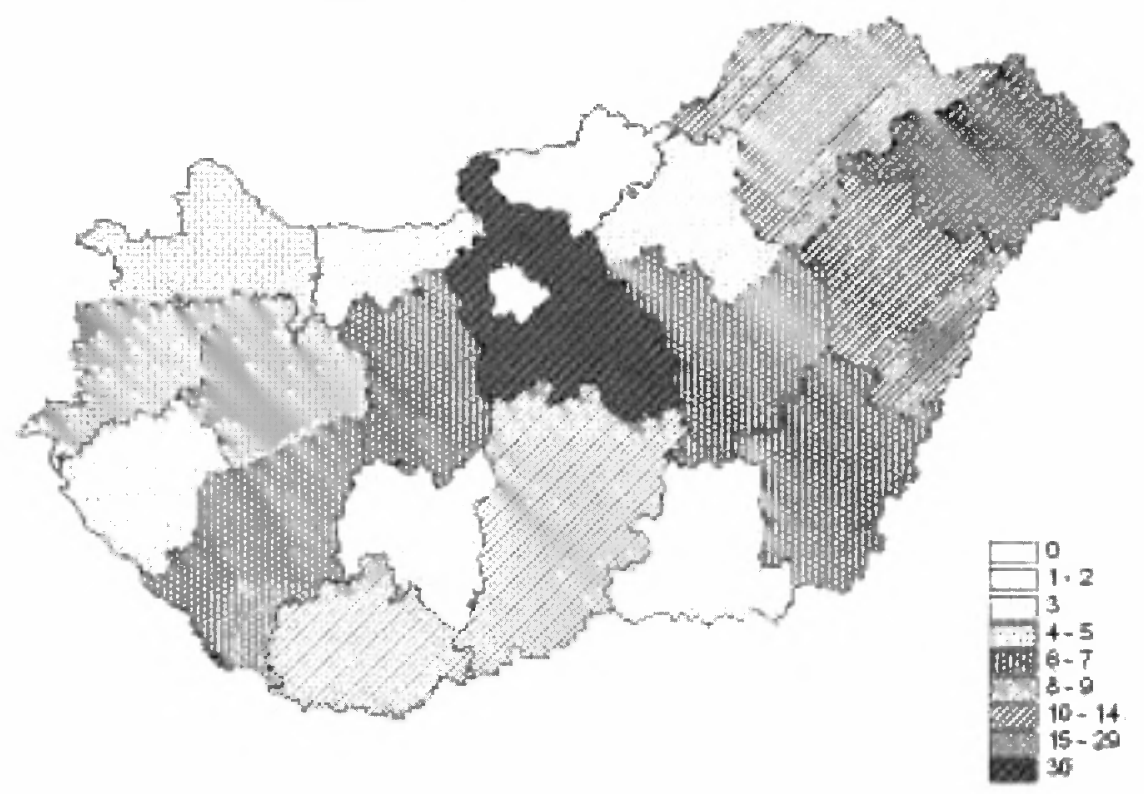

Forrás: Magyar Statisztikai Évkönyv (2006).

$\mathrm{Az}$ új városok megyénkénti területi megoszlását szemléltető 4. ábrán jól látható, hogy az új városok közül messze Pest megyéból való a legtöbb. Ha nem csupán ennek volumenét, hanem az 1990 elôtti városok számával összevetett arányát is megvizsgáljuk, akkor is Pest megye kerül a lista élére. Mindez tehát a Budapest környéki gyors városodást mutatja, ami mindenekelőtt az ütemes szuburbanizációnak tudható be.

Jelentős számú várost avattak még az ország keleti, északkeleti részében, Szabolcs-Szatmár-Bereg, Hajdú-Bihar és Borsod-Abaúj-Zemplén megyében (4. ábra). Mindez már korántsem a gyors elő- és kisvárosi fejlődésnek köszönhető, hanem az egyébként is elmaradottnak számító térség fellendülését hivatott elősegíteni, tehát mintegy „megelőlegezett” a várossá avatás egy része. Az imént említett megyék közül Szabolcs-Szatmár-Bereg és Hajdú-Bihar a rendszerváltáshoz képest több mint duplájára növelte városainak számát, ugyanakkor Borsod-Abaúj-Zemplén már korábban is az egyik legtöbb várossal rendelkező megyénknek számított.

Ha a másik végletet nézzük, az ország nyugati és középső régióiban különösen alacsony az új városok száma (4. és 5. ábra). Mindez összefügg a településhálózat sajátosságaival is, hiszen egyes megyékben - például Vasban, Zalában vagy Tolnában - rendkívül nagy az aprófalvak száma, így kevés az olyan település, amely városi szerepkörre alkalmas, és ha mégis létrejött egy-egy új város, az bizonyos tekintetben nem felel meg a városodás egy-egy kritériumának (ld. Öriszentpéter vagy 
Zalalövő alacsony népességszáma). Az 1. táblázat mutatja azt is, hogy ezek a megyék korábban sem számítottak a városok számában élenjáróknak Magyarországon.

Ki kell emelnünk még Nógrád megyét is, ahol az 1989. évi várossá avatások óta új város nem született, és ez a folyamat valószínüleg a következö években-évtizedekben is folytatódni fog, tekintettel arra, hogy e megyében még nagyközség sincs.

\section{TÁBLÁZAT}

$A z$ új városok régi városokhoz viszonyitott aránya

(The Rate of the New and the Old Cities Compared to Each Other)

\begin{tabular}{lc}
\hline Megye & Arány \\
\hline Pest & 2,14 \\
Baranya & 1,60 \\
Szabolcs-Szatmár-Bereg & 1,50 \\
Hajdú-Bihar & 1,10 \\
Fejér & 1,00 \\
Bács-Kiskun & 0,82 \\
Györ-Moson-Sopron & 0,80 \\
Borsod-Abaúj-Zemplén & 0,79 \\
Somogy & 0,75 \\
Veszprém & 0,56 \\
Vas & 0,57 \\
Békés & 0,50 \\
Heves & 0,50 \\
Jász-Nagykun-Szolnok & 0,50 \\
Zala & 0,50 \\
Komárom-Esztergom & 0,38 \\
Csongrád & 0,29 \\
Tolna & 0,29 \\
Nógrád & 0,00 \\
\hline
\end{tabular}

Forrás: A Magyar Köztársaság helységnévtára (2007). 


\section{5. ÁBRA}

A várossá nyilvánitások időbeli megoszlása

(The Years of the City-proclamations)

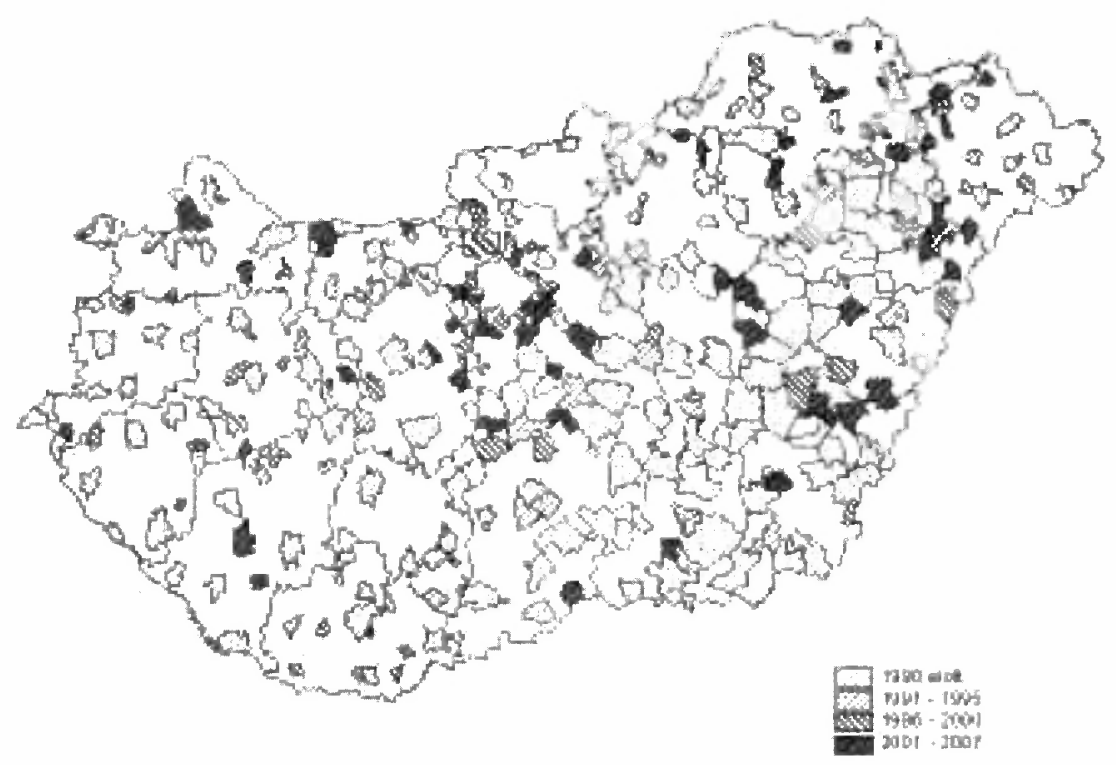

Forrás: A Magyar Köztársaság helységnévtára (2007).

$\mathrm{Az}$ új városok számának rohamos növekedése miatt jelentősen megnött a városi rangú települések aránya a településhálózaton belül (2. táblázat). Míg a rendszerváltás előtt csaknem minden huszadik település számított városnak, addig napjainkban tízből egy település sorolható ebbe a kategóriába. Hasonlóan megnövekedett a városi lakosok aránya a teljes népességen belül. Amíg 1980-ban csak minden második ember számított városlakónak, addig 2007-re már elmondhatjuk, hogy a népesség kétharmada városokban él. Mindez azonban Európában továbbra sem jelent kiugró értéket, Magyarország a közepesen városodott országok közé tartozik (Dövényi 2003).

A városodottság mértéke a legjelentősebbnek Közép-Magyarországon és az alföldi régiókban tekinthető ( 6 . ábra). Ha azonban összevetjük mindezt a tényleges állapotokkal (az itteni városok városi szerepkörével, az infrastruktúra és a szolgáltatások színvonalával, az életmóddal stb.), akkor igazolható Beluszky Pál azon véleménye, miszerint egyes alföldi megyék városodottsága - Hajdú-Bihar, Csongrád, JászNagykun-Szolnok - túlzott (Beluszky 2003). Eközben számos dunántúli megye közepes mértékủ városodottsággal bír, ám itt, mint már fentebb is említettük, a településszerkezet sajátosságaiból adódóan nehezen lehetne a városok számát bỏvíteni. Legkevesbé városodott megyénk Nógrád, köszönhetően többek között annak is, hogy az utóbbi 17 évben új várost nem avattak e térségben. 
Szepesi Gábor : A rendszerváltozás utáni várossá avatások Magyarországon.

Tér és Társadalom 22. évf. 2008/2. 53-70. p.

\section{TÁBLÁZAT}

A városok számának és a városi lakosok arányának megyénkénti megoszlása (The Distribution of the Number of Cities and the Number of Urban Population by Counties)

\begin{tabular}{lcccc}
\hline \multicolumn{1}{c}{ Területi egység } & $\begin{array}{c}\text { Városok } \\
\text { száma }\end{array}$ & $\begin{array}{c}\text { Összes } \\
\text { település }\end{array}$ & $\begin{array}{c}\text { A városi jogál- } \\
\text { lású települé- } \\
\text { sek aránya (\%) }\end{array}$ & $\begin{array}{c}\text { A várasín } \\
\text { népesség } \\
\text { anya(\%) }\end{array}$ \\
\hline Budapest & 1 & 1 & 100 & $100 \%$ \\
Pest & 44 & 186 & 23,7 & $55,7 \%$ \\
$\quad$ Közép-Magyarország & 45 & 187 & 24,1 & $82,4 \%$ \\
\hline Fejér & 12 & 108 & 11,1 & $54,2 \%$ \\
Komárom-Esztergom & 11 & 76 & 14,5 & $63,3 \%$ \\
Veszprém & 14 & 217 & 6,5 & 60,3 \\
$\quad$ Közép-Dunántúl & 37 & 401 & 9,2 & 58,8 \\
\hline Györ-Moson-Sopron & 9 & 182 & 4,9 & 57,8 \\
Vas & 11 & 216 & 5,1 & 57,0 \\
Zala & 9 & 257 & 3,5 & 55,7 \\
$\quad$ Nyugat-Dunántúl & 29 & 655 & 4,4 & 57,0 \\
\hline Baranya & 13 & 301 & 4,3 & 63,0 \\
Somogy & 14 & 245 & 5,7 & 49,1 \\
Tolna & 9 & 108 & 8,3 & 53,8 \\
$\quad$ Dél-Dunántúl & 36 & 654 & 5,5 & 56,0 \\
\hline Borsod-Abaúj-Zemplén & 25 & 357 & 7,0 & 56,4 \\
Heves & 9 & 119 & 7,6 & 44,5 \\
Nógrád & 6 & 129 & 4,7 & 43,7 \\
$\quad$ Észak-Magyarország & 40 & 605 & 6,6 & 51,2 \\
\hline Hajdú-Bihar & 21 & 82 & 25,6 & 79,7 \\
Jász-Nagykun-Szolnok & 18 & 78 & 23,1 & 66,9 \\
Szabolcs-Szatmár-Bereg & 25 & 229 & 10,9 & 48,8 \\
$\quad$ Észak-Alföld & 64 & 389 & 16,5 & 64,6 \\
\hline Bács-Kiskun & 20 & 119 & 16,9 & 65,1 \\
Békés & 18 & 75 & 24,0 & 69,2 \\
Csongrád & 9 & 60 & 15,0 & 71,9 \\
$\quad$ Dél-Alföld & 47 & 254 & 18,5 & 68,4 \\
\hline Ország összesen & 298 & 3145 & 9,5 & 66,2 \\
\hline Foras:A Magyar Kon & & & \\
\hline
\end{tabular}

Forrás: A Magyar Köztársaság helységnévtára (2007). 


\section{6. ÁBRA}

A városi lakosok aránya hazánk megyéiben (\%)

(The Percentage of the Urban Population in Hungarian Counties)

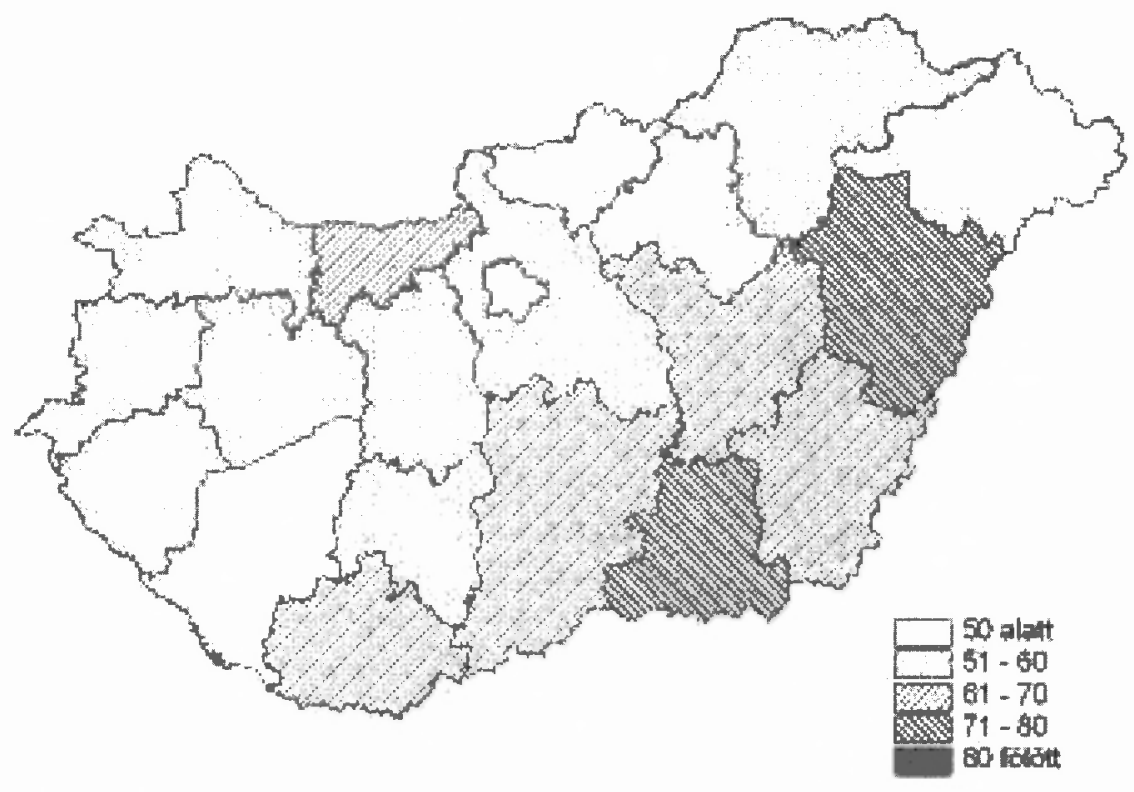

Forrás: A Magyar Köztársaság helységnévtára (2007).

Részben a településszerkezetnek is köszönhetően, szoros korrelációt nem lehet kimutatni a GDP országon belüli területi megoszlása és a városodottság mértéke, illetve az új városok területi elhelyezkedése között. Ugyan a Nyugat-Dunántúl megyéi a bruttó hazai értéket tekintve messze kiemelkednek, mindez azonban nem jelenti azt, hogy a városodottság mértékében is kimagaslóak lennének. A legvárosodottabb megyéink a GDP-t tekintve éppen az átlag alatt helyezkednek el.

Bár sok ország esetében a gazdasági fejlettség fokmérője a városi lakosok aránya, Magyarországon ilyen összefüggés nem mutatható ki, jóllehet azt el kell ismerni, hogy a GDP alapján alacsony értékkel rendelkező megyéink - például Nógrád vagy Heves - egyben a városodottság mértékét tekintve is sereghajtóknak számítanak. Ugyanakkor az új városok elhelyezkedése azt sugallja, hogy a várossá avatások átlagnál nagyobb mértéke - például Borsod-Abaưj-Zemplén megyében - éppen a gazdasági fellendülést hivatott elösegíteni.

\section{A népesség szerepe a várossá válásban}

A már többször citált 1999. évi XLI. törvény a népesedési helyzetet, pontosabban „a nagyközség népességének alakulását, demográfiai, társadalmi szerkezetének jellemzőit" csak egyik kritériumként jelöli meg a várossá válással kapcsolatosan. 
Közismert, hogy a városi besorolás elvei országonként eltérnek, ám az Európai Unióhoz tartozó legtöbb ország esetében valamilyen népességszámhoz (általában 2000 föhöz) kötik a városi rang megszerzését (Máthé 1994). A magyarországi városokkal foglalkozó tanulmányok egy részében is megfigyelhető a kutatók részéről felmerülő olyan igény, hogy népességszámhoz kössék a városi rangot. Az 1970-es években például felvetődött egy 5 ezer fỏs alsó határ, ami az 1990-as évek végére 1500-2000 fóre módosult (Zoltán 2002). Ugyanakkor a kutatók egy másik csoportja önmagában nem tartja elégségesnek a népességszám alapján megszabott kritériumot, mondván, a városban élők száma nem tükrözi azt, hogy az adott település rászolgált-e a várossá avatásra.

Hazánkban a rendszerváltás előtti évtizedekben városi rangot a 10-20 ezer fövel rendelkező települések kaptak. 1990 után viszont ebben a tekintetben is jelentős változás következett be, hiszen amint az a 7. ábrán látható, a várossá váláshoz már alacsonyabb népességszám is elegendőnek bizonyult, és ebben még a rendszerváltás óta eltelt 16 év alatt is megfigyelhető enyhülés, olyannyira, hogy a 2005. évi várossá avatások alkalmával már egy alig 1000 fơs település, Pálháza is megkaphatta ezt a rangot. Általában elmondható, hogy az alacsony számú, 2-3 ezer fós lakossággal rendelkező települések az utóbbi 5-6 évben válhattak könnyebben várossá, bár már az 1990-es évek elejéröl is van erre példa (ld. Balatonföldvár). Az alacsony népességszám mindenekelőtt olyan településeknél bizonyult hangsúlytalannak, amelyek előnyös földrajzi helyzettel rendelkeznek, különösen idegenforgalmi szempontból (ld. Öriszentpéter, Zalakaros, Visegrád). Feltúnő, hogy ilyen települések elsősorban az ország fejlettebb, nyugati felében találhatók, miközben az alföldi, "túlvárosodott" térségben továbbra is túlnyomórészt az 5 ezer fö feletti nagyfalvak váltak várossá. Ha az ország egész területén ez utóbbi népességszám lett volna az alsó határ, akkor 48-cal kevesebb városavatásra került volna sor a rendszerváltozás óta! $\mathrm{Az}$ is figyelemre méltó, hogy a Budapest környéki agglomeráció települései is általában 5-10 ezer, sőt némelyik 15 ezer fö feletti népességgel jutott városi ranghoz. Ugyan Érd sorsára egyik sem jutott - hiszen ez utóbbi település csak 1979-ben, közel 40 ezer fönyi lakossággal, mint Európa akkor legnépesebb községi jogállású települése kapta meg a városi rangot -, ám így is szemmel látható kontraszt alakult ki azokhoz a térségekhez képest, amelyekben 1-2000 fő elegendőnek bizonyult a városi címhez. Az agglomerációs települések népességszámukat tekintve olyan fejlődést produkáltak, hogy szinte „kikövetelték” maguknak a városi rangot. 
Szepesi Gábor : A rendszerváltozás utáni várossá avatások Magyarországon.

Tér és Társadalom 22. évf. 2008/2. 53-70. p.

\section{7. ÁBRA}

Az ủj városok népessége a várossá válás évében

(The Population of the New Cities in the Year They Became City)

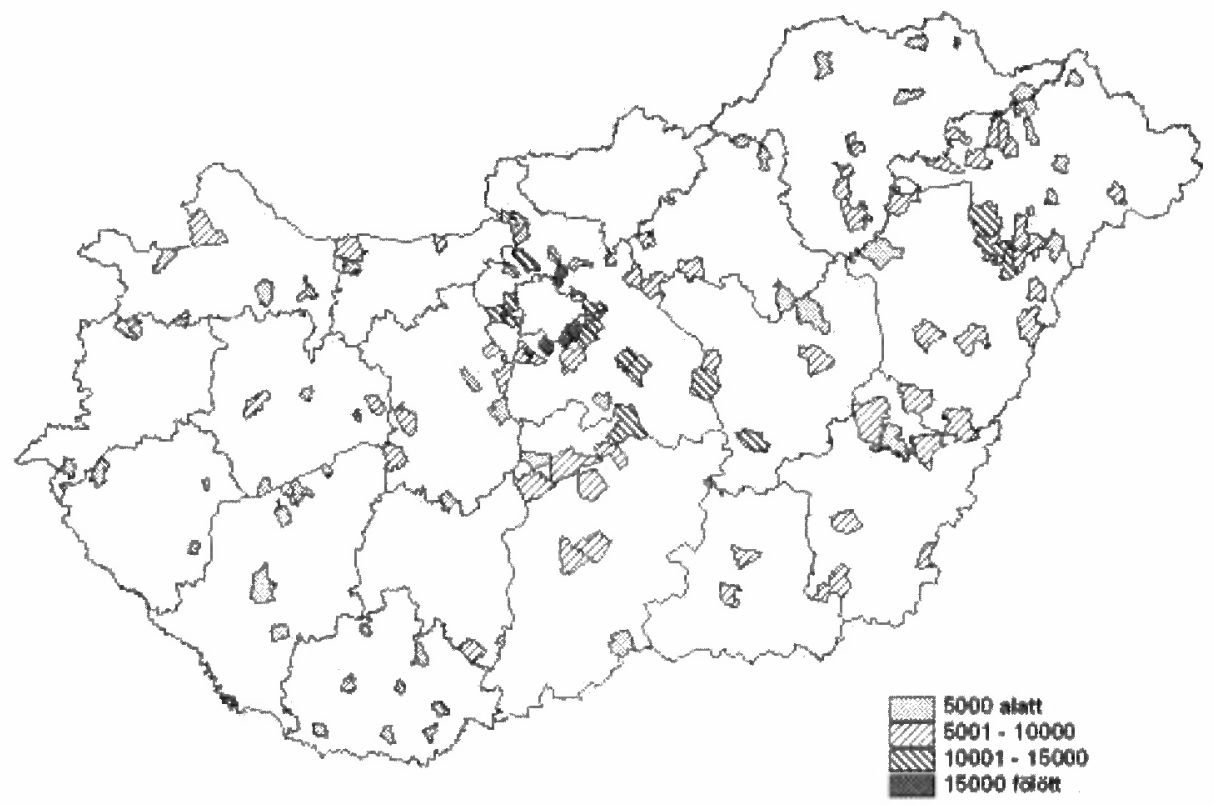

Forrás: A Magyar Köztársaság helységnévtára (2007).

A várossá avatásoknak köszönhetően jelentősen módosult a kisvárosok aránya a településhálózaton belül (3. táblázat). Ma a városi lakosság háromnegyede kisvárosokban él, miközben a városi településeken belül a kisvárosok aránya közel $80 \%$. Ez tehát a városállomány elaprózódását eredményezi (Dövényi 2003).

\section{TÁBLÁZAT}

Hazánk városainak népességszám szerinti kategorizálása (2007)

(The Categories of the Cities by the Number of Population)

\begin{tabular}{|c|c|c|c|c|}
\hline \multicolumn{2}{|c|}{ Kategória } & Új város & Régi város & Összes város \\
\hline \multicolumn{2}{|c|}{1 millió fö fölött } & 0 & 1 & 1 \\
\hline \multicolumn{2}{|c|}{$100000-1000000$ fö } & 0 & 8 & 8 \\
\hline \multicolumn{2}{|c|}{$20000-100000$ fö } & 1 & 53 & 54 \\
\hline \multirow[b]{2}{*}{ Kisvárosok } & $10000-20000$ fö & 23 & 57 & 80 \\
\hline & $\begin{array}{l}5000-10000 \text { fó } \\
2000-5000 \text { fö } \\
2000 \text { fö alatt }\end{array}$ & $\begin{array}{c}59 \\
47 \\
4\end{array}$ & $\begin{array}{c}36 \\
9 \\
0\end{array}$ & $\begin{array}{c}95 \\
56 \\
4\end{array}$ \\
\hline
\end{tabular}

Forrás: A Magyar Köztársaság helységnévtára (2007). 
A várossá váláshoz sokszor elegendő alacsony népességszám miatt valamennyi új város kisvárosként lépett a városi települések sorába. Ennek következtében a legnépesebb vagy közepesen népes városok közé nem ékelődött be egyetlen új városi település sem. A legfrissebb népesedési adatok azt mutatják, hogy mindössze egy város, Gyál lakossága haladja meg a 20 ezer fỏt, ezzel pedig a népességszám alapjản felállított listán az 56. helyet foglalja el hazánk városai között. Az első száz legnépesebb város között mindössze tíz új városi települést fedezhetünk fel, a másik oldalról viszont néhány olyan városunk is van, amelyik még a rendszerváltás elött szerezte meg rangját, mégis a lista végén foglal helyett (pl. Fonyód, Rétság, Pétervására).

Ha az új városi települések népesedési folyamatait vizsgáljuk várossá avatásuk óta (8. ábra), meglehetősen heterogén kép alakul ki az ország területén.

\section{8. ÁBRA}

Új városaink népesedési veszteségei és nyereségei

(Increase and Decrease of the Population in the Latest Proclamed Cities)

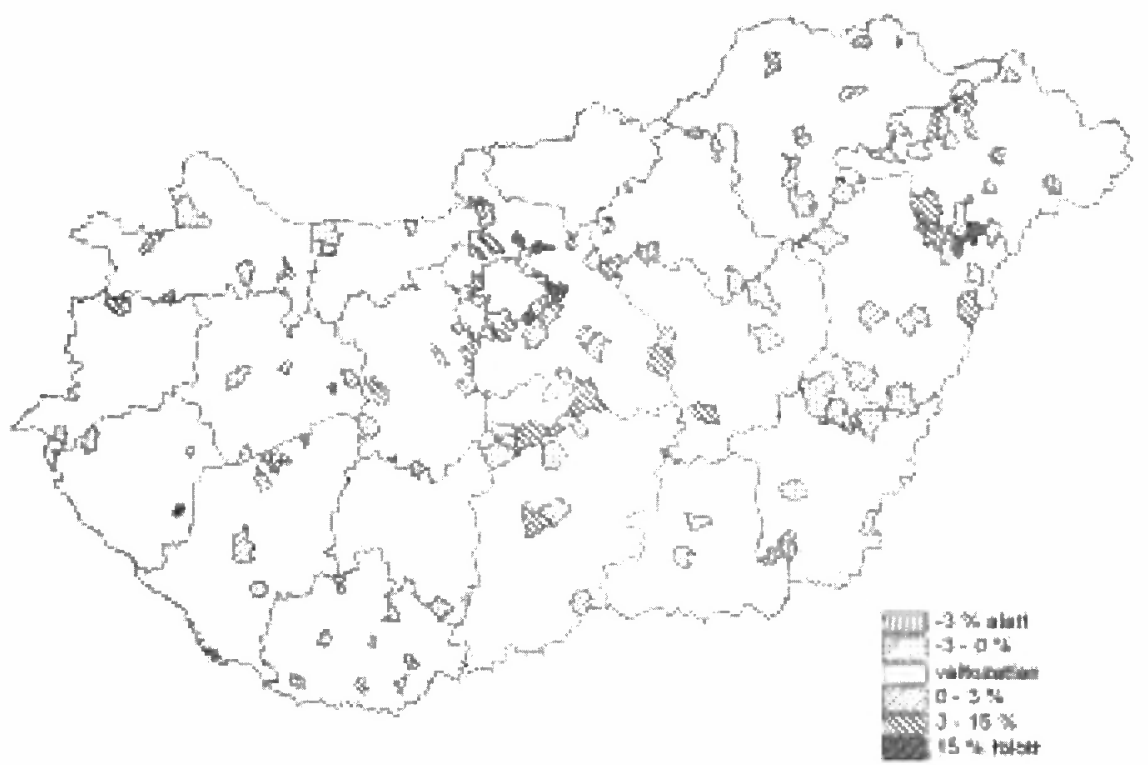

Forrás: A Magyar Köztársaság helységnévtára (2007) alapján saját számítás.

Alapvető tény, hogy városhálózatunk fejlödése csökkenő népességủ országban zajlik. Mivel hazánk népessége az 1980-as évek eleje óta fogyatkozik, a városnövekedés folyamata ezzel párhuzamosan megszünt, tehát a városrobbanás átadta a helyét a városstagnálásnak, mindenekelött a népességszám tekintetében (Beluszky 2000). Sőt, az 1990-es években a városok népessége gyorsabban csökkent, mint az egész országé, hiszen 1998-ban már csak az 1990. évi népesség 95,7\%-a tartózkodott a városokban. Ezek az állítások azonban a városhálózat egészét általánosságban érintik (és az utóbbi folyamatot mindenekelőtt két nagyváros, Budapest és Miskolc 
népesedési veszteségei élénkítik), ha csak az új városokra koncentrálunk, akkor sokkal árnyaltabb a kép.

Az utóbbi évtizedekben Magyarország is eljutott az urbanizáció egy újabb szakaszába, nevezetesen az elővárosi, kisvárosi, illetve a falusi térségek fejlỏdési időszakához, ami egyfajta dezurbanizációt indít el, föként a közép- és nagyvárosokban (Becsei 2001). Ami azonban ez utóbbi városoknak veszteség, az az új kisvárosok szempontjából nyereség, így többek között az urbanizációs ciklusokban bekövetkező változások is eredményezték azt, hogy az új városok több mint felében még mindig - bár néhol csak minimális - népességgyarapodást figyelhetünk meg az utóbbi években. Azt is meg kell jegyezni azonban, hogy az „ellenvárosodás” folyamata nem csupán a kisvárosok népességét gyarapítja, hiszen a városi munkahelyek számának csökkenése, az égbe szökő lakásárak és a magasabb megélhetési költségek miatt többen is a falvakba (például a szülőfalujukba) költözést választották (Beluszky 2003).

Ha a területi megoszlást figyeljük, megállapítható, hogy a népességgyarapodást mutató új városok elsỏsorban a Közép-magyarországi régióban, illetve az Alföld (főként a Tiszántúl) területén helyezkednek el. Különösen markáns növekedési értékek figyelhetốk meg a Budapest körüli agglomerációban; ez egyértelmủen az urbanizációs folyamatok szuburbanizációvá való átalakulásával magyarázható. Mindennek köszönhető, hogy Veresegyház népessége például a várossá váláshoz képest eltelt idó alatt több mint felével emelkedett, de lendületesen gyarapodott Pécel, Gyál és Göd népessége is az agglomerációban. Ebbe a sorba ékelődik be még Zalakaros is, ahol a népességszám százalékos változása ugyan feltűnően magas (több mint húsz százalék), ám volumenét tekintve (mintegy 300 fó) ez már korántsem annyira kirívó. ${ }^{3}$

Ha a legnagyobb mértékü népességcsökkenést produkáló új városokat nézzük, nem rajzolódik ki egy olyan jól elhatárolható régió, ahonnan ilyen jellegủ települések kerülnének ki. Ellenben feltủnő az országhatárok közelében elhelyezkedő városok egy részénél a népesség fogyása, és sok a megyehatárokon fekvő ilyen település is. Mindez arra utal, hogy a periférikus elhelyezkedés (legyen az bármilyen megközelítésből az) nem kedvez a népességgyarapodásnak, az emberek elsősorban a központi fekvésủ településeket választják lakóhelyüknek.

A 3\%-nál kisebb népességveszteségeket elszenvedö települések is szórtan helyezkednek el az országban, ám észrevehető, hogy ezek többsége a nagyfalvas, alföldi régiókban fekszik, amelyek gazdasági fejlettségüket tekintve is le vannak maradva az országos átlaghoz képest, tehát nem számítanak népességet vonzó régiónak hazánk területén.

Érdemes megvizsgálni a népességszámot alapvetően befolyásoló két tényező, a természetes szaporulat és a vándorlási különbözet alakulását új városainkban.

Ha az előbbit nézzük, mindenekelött rögzítenünk kell, hogy ma Magyarország egyetlen megyéjében sem figyelhetjük meg a születési és a halálozási ráta pozitív mérlegét, azaz mindenütt a természetes fogyás jelensége érvényesül. Ugyanakkor mégis vannak olyan települések, amelyek természetes szaporulatot tudnak felmutatni. Ám ezek a települések elsősorban alacsony lakosságszámú, falusi települések, és csak kevés a városi rangú. Ez utóbbiak között szinte kizárólag új városokat találha- 
Szepesi Gábor : A rendszerváltozás utáni várossá avatások Magyarországon.

Tér és Társadalom 22. évf. 2008/2. 53-70. p.

tunk. Földrajzilag ezek elsősorban a budapesti agglomerảcióban helyezkednek el (Veresegyház, Fót, Gyál). A pozitív mérlegnek több összetevője lehet, mindenekelött az, hogy a szuburbanizációval sok fiatal vagy középkorú pár költözött ki, ahol még nagyobb a gyermekvállalási hajlandóság, és többek között azért is választották a nagyváros közeli, ám mégis ,vidéki” létet, hogy gyermekeiknek nyugodtabb, kellemesebb kisvárosi miliôt tudjanak biztosítani.

Az új városok közül kiemelkedik Hajdúhadház ( 8,7 ezrelék) és Téglás (3,3 ezrelék) magas természetes szaporulata. A Debrecen közeli két kisváros mindennek köszönhetően dinamikus népességnövekedést mutat a rendszerváltás óta.

Településeink többségében a halálozások száma meghaladja a születések számát. Igaz ez az új városokra is, így a népességszám csökkenéséhez mindenekelőtt nem a vándorlási veszteség, hanem a természetes fogyás jảrul hozzá. Magas értékeket (például Balatonföldvár: -13\%, Sásd: $-8,9 \%$ ) elsősorban a kis lélekszámú új városoknál tapasztalhatunk, ahol a volumenében egyébként a városok átlagához képest nem feltünően nagy különbség is érzékenyen érinti a születések és a halálozások egyenlegét.

A természetes fogyás túlsúlya arra enged következtetni, hogy önmagában a várossá válás általában nem indít el az ország egészére jellemző tendenciáknak ellentmondó folyamatokat, azaz hiába lett város egy település, az nem eredményezte a születésszám emelkedését, dacára az esetlegesen jobb életkörülményeknek. Ebböl következően azt, hogy az új városok többségének népességszáma mégis gyarapszik, elsösorban a másik tényező, a vándorlási különbözet vizsgálata magyarázza meg.

A vándorlási mérleget tekintve már jóval több újonnan várossá nyilvánított település könyvelhet el aktívumot. Ez mindenekelött a népességszámot tekintve egyébként is növekvő értéket produkáló Budapest környéki agglomerációban figyelhető meg. A jelenség a már több ízben is említett szuburbanizációval magyarázható.

A szuburbanizáció jelensége a rendszerváltozás előtt csupán nyomokban jelent meg, és akkor is elsősorban a budapesti városrégióban (Dövényi 2003). Azóta azonban jelentős változások zajlottak le, amelyek lehetővé tették a Nyugat-Európában már a II. világháború után elterjedt folyamat kibontakozását. Ezek közé tartozik a lakásprivatizáció megjelenése, a lakásszerzést és birtoklást korlátozó intézkedések feloldása, ami az alapját képezte a szuburbanizációnak: a nagyvárosi lakosok egy része a korábban megszerzett lakását a piaci árnál magasabban értékesítette, majd az ebből származó profitból az agglomerációban egy jóval nagyobb és fajlagosan olcsóbb lakást tudott vásárolni. További változást jelentett még az önkormányzatiság megjelenése is, melynek nyomán új energiák szabadultak fel, megerösödött a helyi politika, miközben elhalványult a központi irányítás szerepe. Ezek nyomán kialakult a „települések versenye” a „sikeres” és „vesztes” városok között. Az előbbiek egyre növekvő gazdasági jelentőséggel bírnak, a veszteseknek viszont nincs érdemi befolyásuk az új gazdasági tér kialakításában. Ahol sok a sikeres település, az a régió lesz a nyertese a gazdasági tér kitöltésének (Enyedi 1996). Ez utóbbi csoportba lehet sorolni az agglomerációs települések jelentős részét, ahol a „siker- 
index" számításának alapját az mutatja, hogy a kitelepedő népességen belül mekkora a magas státuszú népesség aránya (Izsák 2003).

A „sikerindex” egyben kifejezi azt is, hogy a szuburbanizációnak manapság már nem csupán a mennyiségi, hanem a minöségi jellemzői is hangsúlyossá váltak. Ami a mennyiségi jellemzőket illeti, először a budapesti agglomerációban tủnt fel a jelenség, méghozzá váratlanul és szinte robbanásszerủen. Amíg az 1980-as évekig Budapest könyvelhetett el pozitív vándorlási egyenleget a környező települések kárára, 1990 után szinte évról évre nőtt az agglomeráció vándorlási nyeresége a fövárossal szemben, ami azt eredményezte, hogy Budapest napjainkban évi mintegy 15 ezer lakost veszít környékével szemben. Ennek, valamint a természetes fogyásnak köszönhetöen Budapest népessége 2005-ben már 1,7 millió fö alá csökkent.

A társadalmi összetétel tekintetében párhuzamot állithatunk a magyar és a klaszszikus észak-amerikai és nyugat-európai szuburbanizáció között, hiszen hazánkban is többnyire a jól szituált, magasan képzett középrétegek voltak a föszereplöi a kiköltözéseknek, növelve ezáltal az érintett települések „sikerindexét”. Ugyanakkor az utóbbi évek lakásépítési konjunktúrảjának köszönhetően egyre több fiatal, az átlagosnál jobb életkörülményeket teremteni képes házaspár választotta a nagyváros közeli életmódot, tehát további csoportok járultak hozzá az új városok gyarapodásához, egyben humán erőforrásainak emelkedéséhez.

A magyarországi szuburbanizáció azonban rendelkezik egy olyan fontos aspektussal, amely Nyugat-Európában kevéssé figyelhető meg. Ez pedig az ún. szegények szuburbanizációja, melynek következtében a szegényebb rétegek olykor menekülésszerúen vándoroltak ki a városokból, hiszen a drága városi életet az alacsonyabb jövedelmüek egy része nem tudja megfizetni, ezért az olcsóbb megélhetést biztosító vidéki térségekbe költözik (Dövényi 2003). Ugyanakkor az „olcsóság”, mint elöny egyre kevesebb agglomerációs település sajátossága már, hiszen - föként a Budapest környéki, ahhoz közelebb fekvő, az átlagosnál népesebb régi és új városokban - az ingatlanárak mindinkább elérik a föváros lakásárait.

Ugyan a bevezetésben már felsoroltuk, hogy milyen tényezök ösztönzik a várossá fejlődést, a szuburbanizáció által érintett települések esetében azonban egyéb motivációs tényezöket is figyelembe kell vennünk (Bajmócy 2002). Ezek közé tartozik mindenekelött a nagyobb lakáshoz jutás igénye (amely az előző bekezdésben említettek miatt egyre kevésbé tünik realitásnak), a családalapításhoz szükséges kedvezőbb feltételek megléte (ezzel magyarázható, hogy miért alakul ki természetes szaporulat a nagyvárosok környéki településeken), a természeti környezet, a levegö tisztasága, a közbiztonság stb. Ugyan a fejlett infrastruktúra általában vonzza az embereket, ám az agglomerációs új városok esetében ennek kiépítése hiányos, ugyanakkor megállapítható, hogy az emberek az imént felsorolt ösztönzö elemek miatt képesek lemondani a kényelem bizonyos szintjéröl.

A szuburbanizáció számos kedvezö következménnyel jár az agglomerációs településeket tekintve. Amellett, hogy az érintett települések gazdasági szempontból is fejlődést mutatnak, a társadalmi szerkezet is átalakul, méghozzá örvendetesen, hiszen 
kedvezőbbé válik a korstruktúra, még magasabbá válik az ott élők státusza, ezáltal növelik a vásárlóeröt és az önkormányzat bevételi forrásait a helyi adók révén.

Ugyanakkor kedvezỏtlen elemnek vehetjük például a szegregációs tendenciák megindulását is. Egyes települések - különösen a lakóparkok számának ugrásszerü növekedése miatt - még jobb helyzetbe kerülnek, ezáltal tovább élezik a társadalmi különbségeket, hiszen az ilyen települések elsösorban a jómódúakat vonzzák. Eközben a nagyváros szempontjából megindul egy rendkívül káros folyamat: a tehetősebb adófizetői réteg elvándorlásával elapadnak a bevételi forrásai, elszegényedésnek indul, és esetleg eladósodhat. Amennyire kedvezővé válik az új városok társadalmi összetétele, olyannyira hátrányos helyzetbe kerülnek a nagyvárosok, hiszen ott elsősorban az alsóbb társadalmi réteghez tartozó, közép- vagy idősebb korú lakosság él, amelyik támogatásra szorulna, ám a bevételek csökkenése miatt a nagyváros ennek biztosítására egyre kevésbé képes (Dövényi-Kovács 1999). További kedvezôtlen jelenség még az új városokban a beépíthető területek arányának csökkenése, illetve a telekárak gyors emelkedése, így gyakran előfordul, hogy az „őslakosok” ellenségesen viszonyulnak az újonnan kitelepülökhöz.

Meg kell jegyezni, hogy Magyarországon az utóbbi években megjelent az urbanizáció legújabb szakasza, az ún. poszt-szuburbanizáció, de ez csupán egy-két, Budapest körüli agglomerációs település (mindenekelött Budaörs) sajátossága. A folyamat lényege, hogy megkezdỏdik a szuburbán téren belüli centrumképződés, azaz kialakulnak a perifériák új centrumai azzal, hogy az ingázás jelentősebbé válik a szuburbán települések között, mint a magváros és a szuburbán régió települései között (Izsák 2003).

Ha az agglomerációk közötti területi különbségeket nézzük, a legmarkánsabb bevándorlási nyereségeket egyértelmüen Budapest környékén figyelhetjük meg. Ám itt is árnyaltabb a kép, tekintve, hogy a legjobb mérleggel a nyugati ( $20 \%$ körül), a délnyugati $(19,5 \%)$ és a keleti $(20,8 \%$ ) szektor rendelkezik. Új városokat valamennyi szektorban találunk (Budakeszi, Tököl, Dunavarsány, Veresegyház, Fót, Pécel), melyek mindegyike lendületes népességnövekedést mutatott az utóbbi években. A többi agglomerációs térség már közel sem ekkora nyertese a szuburbanizációnak. Ezek közül kiemelkedik a Balaton körüli agglomeráció, amely sajátos típust képvisel, hiszen nem egy-, hanem többközpontú, és hiányzik egy meghatározó, 100 ezer vagy akár 50 ezer fónél több lakossal rendelkezỏ városi település. Figyelemre méltó még a nyugati határszéleinken lévő kisebb agglomerációk bevándorlási nyeresége is. Ugyanakkor az Alföldön (Kecskemét és Szeged kivételével) egyáltalán nem jellemzỏ a szuburbanizáció nyomán a kisvárosokba történő gyors bevándorlás.

Azonban túlságosan egyoldalú képet festenénk, ha csak az agglomerációs települések pozitív vándorlási egyenlegét tüntetnénk fel. Elszórtan ugyan, de az ország különböző pontjain találhatunk még feltủnően magas bevándorlási mutatóval rendelkező településeket. Ezek általában kedvező egyedi adottságokkal, illetve az idegenforgalom különféle vonzó tényezőivel rendelkező települések, többnyire a Dunántúlon (pl. Zalakaros: 22,4\%, Velence: 21,6\%). 
$\mathrm{Az}$ új városok közül viszonylag kevés sorolható a vándorlási veszteségekkel sújtott települések közé. Ilyen vidékeket találhatunk mindenekelött a depressziós alföldi térségben, föleg Hajdú-Bihar és Békés megyében (pl. Dévaványa, Füzesgyarmat, Létavértes), ahol az elvándorlás nem csupán megyén belüli elköltözést jelent, hanem az ország fejlettebb régióiba való migrációt is. Még a legújabb városaink közé felemelkedő Csorvás is passzívumot könyvelhet el a vándorlási egyenlegében.

A negatív értékkel bíró települések másik csoportjába olyan településeket sorolhatunk, amelyek nem nyertesei, hanem vesztesei voltak a szuburbanizációs folyamatoknak. Ezek elsősorban a nagyvárosok szükebb-tágabb peremterületein elhelyezkedő, a centrumból kitelepülő népesség számára kevésbé vonzó feltételeket kínálni tudó települések (Szentlórinc, Polgárdi), melyek lakosai a kisvárosi létet akár falusi életmódra is hajlandóak lecserélni. Ilyen települések környékén éppen ezért azt lehet megfigyelni, hogy a közeli falusi települések sokkal inkább vándorlási nyereségnek örvendhetnek, mint a városok.

$\mathrm{Az}$ imént felsorolt példák arra utalnak, hogy önmagában a várossá válás nem mindenütt elegendő ahhoz, hogy egy település meg tudja tartani népességét, különösen olyan esetekben nem, ha az adott város vagy térség nem tud kellően vonzó feltételeket nyủjtani az ott élőknek.

Összességében megállapítható, hogy a népességszám, mint a várossá válás kritériuma csak az ország egy meghatározott részén, különösen az alföldi régióban és a budapesti agglomerációban számitott hangsủlyosnak, más térségekben viszont, ahol egyéb kritériumok váltak relevánssá (pl. az idegenforgalmi vagy egyéb kedvező egyedi adottságok) kifejezetten lényegtelen tényezőnek minösült. Azt is meg kell azonban jegyezni, hogy a szerény népességszám csak kevés városi funkció megteremtésére ad alkalmat, a népesebb települések a funkciókat tekintve komplexebb képet tudnak kialakítani.

A rendszerváltás nyomán létrejött ủj városok immár nem a népesség számával emelkednek ki, hanem sokkal inkább hangsúlyos az a vonzáskörzet, amit kielégítően el kell látniuk ( $R$ udl 2002).

Ugyanakkor a várossá fejlődés az érintett települések többségénél kedvező folyamatokat indított el a népességszám tekintetében, ám hozzá kell tenni, hogy mindezt nem rohamos természetes szaporulatuknak köszönhetik, hanem más, sok esetben (nagyobb) városi település rovására érték el.

\section{Jegyzetek}

${ }^{1}$ Megjegyzendő, hogy a városfejlődés elősegitésére volt hivatott a válságtérségekben a Területfejlesztési Alap, amelyet az 1990-es években hoztak létre, ám késöbb kiderült, hogy sem ez, sem az 1996-ban jóváhagyott területfejlesztési koncepció nem tudta érdemben befolyásolni a területi folyamatokat (Beluszky 2000). Ugyanakkor potenciális anyagi előnyt jelenthet még a pályázati úton megszerezhetỏ támogatások elnyerése, illetve a várossá válás után betelepülő vállalkozói (esetleges külföldi) tỏke is.

${ }^{2}$ Az 1991-es évben ugyan 8 várossá nyilvánításra is sor került, ám mivel Hajdúhadház és Téglás, továbbá Balatonboglár és Balatonlelle az addig összevont városok szétválásával jött létre, így a városok száma összességében nem nyolccal, hanem hattal nőtt, hiszen Hajdúhadháztéglás és Boglárlelle kikerült a számításokból. 
Szepesi Gábor : A rendszerváltozás utáni várossá avatások Magyarországon.

Tér és Társadalom 22. évf. 2008/2. 53-70. p.

${ }^{3}$ A térképen külön kategóriát képeznek a változatlan népességszámú települések. Ezek magas arảnya nem egyfajta „statisztikai csoda”, hanem azok a települések tartoznak ide, amelyek a 2005-ös, esetleg a 2004-es évben váltak városokká, így a bázisérték és az aktuális népességszám értéke megegyezik.

\section{Irodalom}

Bajmócy P. (2002) A szuburbanizációt kiváltó okok a vidéki Magyarországon. - Abonyiné Palotás J.Becsei J.-Kovács Cs. (szerk.) A magyar társadalomföldrajzi kutatás gondolatvilága. Ipszilon Kiadó és Pedagógiai Szolgáltató Kft., Szeged. 247-255. o.

Becsei J. (2001) Fejezetek az általános társadalmi földrajz tanulmányozásához. Egyetemi jegyzet (második rész). IPSZILON Kiadó és Pedagógiai Szolgáltató Kft., Budapest.

Beluszky P. (2000) Adalékok a városállomány 1990 utáni átalakulásához. - Horváth Gy.-Rechnitzer J. (szerk.) Magyarország terïleti szerkezete és folyamatai az ezredfordulón. MTA Regionális Kutatások Központja, Pécs. 115-129. o.

Beluszky P. (2003) Magyarország településföldrajza. Altalános rész. Dialóg Campus Kiadó, Budapest-Pécs.

Beluszky P.-Gyơri R. (1999) A magyarországi városhálózat és az EU-csatlakozás. - Tér és Társadalom. 1-2. 1-30. o.

CompLex CD Jogtár. (2008) CompLex Kiadó, Budapest.

Dövényi Z. (2003) Településrendszer. - Perczel Gy. (szerk.) Magyarország társadalmi-gazdasági földrajza. Egyetemi tankönyv. Második, átdolgozott kiadás. ELTE Eötvös Kiadó, Budapest. 521-562. o.

Dövényi Z.-Kovács Z. (1999) A szuburbanizáció térbeni-társadalmi jellemzői Budapest kömyékén. Földrajzi értesitöo. 1-2. 33-57. o.

Enyedi Gy. (1996) Regionális folyamatok Magyarországon az átmenet időszakában. Hilscher Rezsö Szociálpolitikai Egyesület, Budapest.

Izsák É. (2003) A városfejlơdés természeti és társadalmi tényezői. Budapest környéke. Napvilág Kiadó, Budapest.

Kiss É. (1997) A várossá nyilvánítás problematikája és a várossá válás jelentősége az önkormányzatok szemszögébỏl. - Földrajzi Értesitỏ. 3. 456-481. o.

A Magyar Köztársaság Helységnévtára. (2007) Központi Statisztikai Hivatal, Budapest.

Magyar Statisztikai Évkönyv. (2006) Központi Statisztikai Hivatal, Budapest.

Máthé M. (1994) Kistérségi funkciók ellátása. Potenciális városok Győr-Moson-Sopron megyében. Falu, város, régió. 5. 39-41. o.

Megyei statisztikai évkönyvek. (1990-2005). Központi Statisztikai Hivatal, Budapest.

Rudl J. (2002) Településközi kapcsolatok és az új kisváros. - Abonyiné Palotás J.-Becsei J.-Kovács Cs. (szerk.) A magyar társadalomfóldrajzi kutatás gondolatvilága. Ipszilon Kiadó és Pedagógiai Szolgáltató Kft., Szeged. 269-278. o.

Szigeti E. (1997) Urbanizáció, városhálózat, várossá nyilvánítás. -Terïleti Statisztika. 1. 66-81. o.

Zoltán Z. (2002) A magyar kisváros-hálózat kiterjedése az 1990-es évtizedben I. - Comitatus. 11-12. 142-151. o.

\section{THE CITY-PROCLAMATIONS IN HUNGARY AFTER THE SYSTEM-CHANGE}

\section{GÁBOR SZEPESI}

The article deals with the methods and the history of the city-proclamations after 1990. The system-change in Hungary was a turning point in the process of the urbanisation. After 1990 the number of cities and the percentage of the urban population rose rapidly. In 1999 a new law was enforced which specified the conditions of becoming a city. But the regional distribution of the new cities is very inequal. A lot of settlement became city in the environs of Budapest, while there are some counties in Hungary, where the number of cities is constant since 1990. The process of the sub-urbanisation is quite different from West-Europe in Hungary. 